\title{
Semantic Features of Kinship Terminology in Modern Chinese Language
}

\author{
A. Z. Mukhamedsadykova \\ Xiamen University, Xiamen, China
}

\begin{abstract}
The article describes semantic features of kinship terminology in modern Chinese language. To make a more complete analysis, the article compares the semantics of kinship terminology in Kazakh, Russian, English and Chinese languages, which belong to various language groups.
\end{abstract}

Keywords: Chinese language, Kazakh language, kinship terminology, semantic feature, comparison

\section{Introduction}

Every nation has its own language, which shows its unique national features and peculiarities. It fully covers both spiritual and material world. And kinship terminology is a group of words which differs by its deep history, system structure and knowable values which is especially important for intercultural communications.

In any language, kinship terminology composes a special symbol system that provides with the information on cultural life of the people who speak the same language. Therefore, kinship terminology is a social symbol. Kinship terminology is an ethno cultural (lingo cultural) symbol. As a lingo cultural symbol it collects various cultural additional meanings in its historic cultural semantics.

\section{Comparison of Kinship Terminology of the First Level}

Before beginning the comparison, first of all, let us describe kinship terminology of the first level. Kinship terminology (亲属称谓语) is a nomination that shows relation of a certain person (relation A) to another one (relation N). For example, let us explain who a "Father" is. He is a man $(\mathrm{N})$ who gave a birth / brought into life (a kind of kinship) to a certain person (A). Foreign scientists named this N Alter and the A Ego. Thus, kinship nominations that have direct relation to this Ego are considered as kinship terminology (一层关系亲属词) of the first level. These kinship relations are of three types, the main of which is marital relations (配偶关系). Because marital relations generate blood (生育关系) and then brotherly (同胞关系) relations. The main and the most used kinship terminology is of the first level. In addition, in any language, kinship terminology of the first level are "Husband" and "Wife" which derive from marital relations and "Father", "Mother", "Son", "Daughter" which derive from blood relations and "Elder brother", "Younger brother", "Elder sister", "Younger sister" which derive from brotherly relations.

We can define close and distant kinship by its degree. For example, father, mother, son and daughter belong

A. Z. Mukhamedsadykova, Ph.D. student, Department of Humanities Studies, Xiamen University. 
to the first-degree kinship. Moreover, elder brother, little brother, elder sister and little sister are of the second-degree kinship. However, as these people live together for a long time their kinship is very close.

Below, let us compare terminology of the first-degree kinship in the four languages. First of all, we should divide marital and blood relations in two separate groups and describe their structural and semantic features. For example, in Chinese language “丈夫”, in Kazakh language "Күйеу”, in English language "Husband”, in Russian language “Муж”. The semantic structure of these words: (一层亲属)↔(配偶关系)+(男性) that is (first-degree kinship)↔(maritalrelations) + (a man). And the structural semantics of “母亲” in Chinese language, “Шеше” in Kazakh language, “Mother”in English language and “Мать”in Russian language: (一层亲属)↔(配偶关系)-(男 性) that is (first-degree kinship)↔(maritalrelations)-(a man). The author shortensthese titles H (husband), W (wife), F (father), M (mother), S (son), D (daughter) in order to give simple and common nominations to this terminology. Chart 1 shows kinship terminology related to marital relations in the four languages.

Chart 1

Kinship Terminology Related to Marital Relations of the First Degree

\begin{tabular}{|c|c|c|c|}
\hline Chinese language & Kazakh language & Russian language & English language \\
\hline 丈夫 & Күйеу & Муж & Husband \\
H & H & H & Wife \\
\hline 妻子 & Әйел & Жена & W \\
\hline
\end{tabular}

In chart 1, we marked $\mathrm{H}$ and $\mathrm{W}$ to define structural semantics having listed the respective words in the four languages in one row. We can see from the chart the correspondence of kinship terminology related to marital relations of the first degree of all four languages. Let us compare below the kinship terminology related to blood relations of the first degree.

Chart 2

Kinship Terminology Related to Blood Relations of the First Degree

\begin{tabular}{|c|c|c|c|}
\hline Chinese language & Kazakh language & Russian language & English language \\
\hline 父亲 & Әке & Отец & Father \\
$\mathrm{F}$ & $\mathrm{F}$ & $\mathrm{F}$ & Mother \\
\hline 母亲 & Шеше & Мать & $\mathrm{M}$ \\
$\mathrm{M}$ & $\mathrm{M}$ & $\mathrm{M}$ & Son \\
\hline U子 & Ұл & $\mathrm{S}$ \\
$\mathrm{S}$ & $\mathrm{S}$ & $\mathrm{S}$ & Daughter \\
\hline 女ル & Қыз & Дочь & $\mathrm{D}$ \\
$\mathrm{D}$ & $\mathrm{D}$ & $\mathrm{D}$ & \\
\hline
\end{tabular}

We can see from the chart the correspondence of kinship terminology related to blood relations. Thus, there is no significant difference.

If we turn to kinship terminology related to brotherly relations we can notify that this group does not correspond as the previous two groups. For example "brother, sister" in English correspond to "Брат, сестра" in Russian and “哥哥、弟弟、姐姐、妹妹” in Chinese correspond to “Аға, Іні, Бауыр, Әпке, Қарындас және Сіңлі" 'in Kazakh. Having analyzed it, we can notice that in Kazakh and Chinese languages significant attention is paid to age difference in brotherly relations. Thus, it precisely shows whether we talk about an elder or a younger 
brother, or an elder or a younger sister.In addition, in Kazakh language a speaker depending on their gender should address to a young woman saying "Қарындас" or "Сіңлі".

Of course, there areelder brother, younger brother, and elder sister, younger sister in English language and старший брат, младший брат, старшая сестра, младшая сестра in Russian language. They correspond to “哥 哥、弟弟、姐姐、妹妹” in Chinese language and “Аға, Іні, Бауыр, Әпке, Қарындас және Сіңлі” in Kazakh language but the age difference is not so important. Furthermore, the semantic structure of these words does not correspond to each other.

The semantic structure of “哥哥、弟弟、姐姐、妹妹” in Chinese language correspond to “Аға, Iнi, Бауыр, Әпке, Қарындас және Сіңлі" in Kazakh language and "brother, sister" in Russian and English languages. In Chart 3, we have compared kinship terminology related to brotherly relations in the four languages. In the chart the semantic structure of the word B (brother): (一层亲属)↔(同胞关系) + (男性) that is (the first-degree kinship)↔(brotherlyrelations) $+($ a man), the semantic structure of S (sister): (一层亲属)↔(同胞关 系)-(男性) that is (the first-degree kinship)↔(brotherly relations)- (a man). In addition we use the symbolse, y to define age difference. That is: " $\rightarrow$ (elder)" " $\leftarrow$ (younger)".

Chart 3

Kinship Terminology Related to Brotherly Relations of the First Degree

\begin{tabular}{|c|c|c|c|}
\hline Қытай тілі & Қазақ тілі & Орыс тілі & Ағылшын тілі \\
\hline $\begin{array}{l}\text { 哥哥 } \\
\text { Be }\end{array}$ & $\begin{array}{c}\text { Aғa } \\
\mathrm{Be}\end{array}$ & \multirow[b]{2}{*}{$\begin{array}{c}\text { Брат } \\
\text { В }\end{array}$} & \multirow[b]{2}{*}{$\begin{array}{c}\text { Brother } \\
\text { B }\end{array}$} \\
\hline $\begin{array}{l}\text { 弟弟 } \\
\text { By }\end{array}$ & $\begin{array}{l}\text { Iні, бауыр } \\
\text { Ву }\end{array}$ & & \\
\hline $\begin{array}{c}\text { 姐姐 } \\
\mathrm{Se}\end{array}$ & $\begin{array}{c}\text { Өпке } \\
\mathrm{Se}\end{array}$ & \multirow[b]{2}{*}{$\begin{array}{c}\text { Сестра } \\
\text { S }\end{array}$} & \multirow[b]{2}{*}{$\begin{array}{c}\text { Sister } \\
\text { S }\end{array}$} \\
\hline $\begin{array}{l}\text { 妹妹 } \\
\text { Sy }\end{array}$ & $\begin{array}{c}\text { Қарындас } \\
\text { Сіңлі } \\
\text { Sy }\end{array}$ & & \\
\hline
\end{tabular}

As we see from the analysis given above there is no any significant difference in kinship terminology of the first degree in Chinese, Kazakh, Russian and English languages. Especially kinship terminology related to marital and blood relations is similar. However, there are age differences in kinship terminology related to brotherhood. Thus, this difference is a major difference between the mentioned languages. If we take a gender difference, kinship terminology varies in all languages.

\section{Comparison of Kinship Terminology of the Second and the Third Degrees}

In Chinese language the semantic structure of kinship terminology of the second and the third degrees is composed from the sum/with the addition of the semantic structure of kinship terminology of the first degree. For example, the semantic structure of “儿媳妇” (Daughter-in-law) in Chinese language: [(一层亲属)〔(生育关

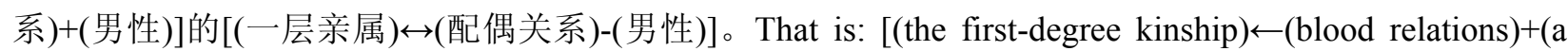
man)]-ның [(the first-degree kinship)↔(marital relations)-(a man)]. We can use the short versions S W.

In Chinese as well as in Kazakh, Russian and English kinship terminology of the second degree is often used in everyday life. Only kinship terminology of the third degree does not correspond in the above mentioned languages. In Chinese 姑父、姨夫、伯母、婶母、堂兄、堂弟、堂姐、堂妹、表哥、表弟、表姐、表妹 
relate to kinship terminology of the third degree. That is why we will conduct analysis based on these words.

Kinship terminology of the second degree of Chinese, Kazakh, Russian and English languages belongs to three main semantic groups. The first one derived from blood relations of the second degree isa direct blood kinship group; the second one derived from marital, blood or brotherly relations of the first degree is a marital kinship group; the third one derived from brotherly and blood relations of the first degree is an indirect blood kinship group. Below we compare Chinese, Kazakh, Russian and English languages based on the above mentioned three groups. First, let us consider a direct blood kinship group.

Chart 4

Direct Blood Kinship Group

\begin{tabular}{|c|c|c|c|c|}
\hline & Chinese language & Kazakh language & Russian language & English language \\
\hline \multirow[t]{2}{*}{1} & $\begin{array}{l}\text { 祖父 } \\
\mathrm{FF}\end{array}$ & $\begin{array}{l}\text { Ата } \\
\text { FF }\end{array}$ & \multirow{2}{*}{$\begin{array}{l}\text { Дедушка } \\
\text { F/MF }\end{array}$} & \multirow{2}{*}{$\begin{array}{l}\text { Grandfather } \\
\text { F/MF }\end{array}$} \\
\hline & $\begin{array}{l}\text { 外祖父 } \\
\text { MF }\end{array}$ & $\begin{array}{l}\text { Нағашы ата } \\
\text { MF }\end{array}$ & & \\
\hline \multirow[t]{2}{*}{2} & $\begin{array}{l}\text { 祖母 } \\
\text { FM }\end{array}$ & $\begin{array}{l}\text { Әже } \\
\text { FM }\end{array}$ & \multirow{2}{*}{$\begin{array}{l}\text { Бабушка } \\
\text { F/MM }\end{array}$} & \multirow{2}{*}{$\begin{array}{l}\text { Grandmother } \\
\text { F/MM }\end{array}$} \\
\hline & $\begin{array}{l}\text { 外祖母 } \\
\mathrm{MM}\end{array}$ & $\begin{array}{l}\text { Нағашы әже } \\
\text { MM }\end{array}$ & & \\
\hline \multirow[t]{2}{*}{3} & $\begin{array}{l}\text { 孙子 } \\
\text { SS }\end{array}$ & $\begin{array}{l}\text { Немере } \\
\text { (SS/SD) }\end{array}$ & \multirow{2}{*}{$\begin{array}{l}\text { Внук } \\
\text { S/DS }\end{array}$} & \multirow{2}{*}{$\begin{array}{l}\text { Grandson } \\
\text { S/DS }\end{array}$} \\
\hline & $\begin{array}{l}\text { 外孙子 } \\
\text { DS }\end{array}$ & $\begin{array}{l}\text { Жиен } \\
\text { (DS/DD) }\end{array}$ & & \\
\hline \multirow[t]{2}{*}{4} & $\begin{array}{l}\text { 孙女 } \\
\text { SD }\end{array}$ & $\begin{array}{l}\text { Немере } \\
\text { (SS/SD) }\end{array}$ & \multirow{2}{*}{$\begin{array}{l}\text { Внучка } \\
\text { S/DD }\end{array}$} & \multirow{2}{*}{$\begin{array}{l}\text { Granddaughter } \\
\text { S/DD }\end{array}$} \\
\hline & $\begin{array}{l}\text { 外孙女 } \\
\text { DD }\end{array}$ & $\begin{array}{l}\text { Жиен } \\
\text { (DS/DD) }\end{array}$ & & \\
\hline
\end{tabular}

Chart 4 shows that Chinese and Kazakh as well as Russian and English are the same. In group 1 there are men of the supreme second generation, in group 2 there are women of the supreme second generation, in group 3 there are men of the next generation and in group 4 there are women of the next generation. If we look at the words in groups 1 and 2 it is clear that Chinese and Kazakh languages define the supreme generation by one's own kin (by father) or kin by mother's side. Nevertheless, in Russian and English languages attention is paid only to gender. The words in groups 3 and 4 in Russian and English also correspond to each other. That is, they distinguish the next generation only by gender. However, in Kazakh they pay attention to whether daughter or son continues the generation and call grandchildren немере (the son's children) ог жиен (the daughter's children). Among these four languages, only Chinese language attaches importance not only to whether son or daughter continues the generation but also to the gender of the generation. Thus, they specially name male and female generation.

Marital kinship group is more complicated than the previous group. Look at Chart 5: 
Chart 5

Marital Kinship Group

\begin{tabular}{|c|c|c|c|c|}
\hline & Chinese language & Kazakh language & Russian language & English language \\
\hline \multirow{2}{*}{1} & $\begin{array}{l}\text { 公公 } \\
\mathrm{HF}\end{array}$ & \multirow{2}{*}{$\begin{array}{l}\text { Қайын ата } \\
\text { H/WF }\end{array}$} & $\begin{array}{l}\text { Свекор } \\
\text { HF }\end{array}$ & \multirow{2}{*}{$\begin{array}{l}\text { Father-in-law } \\
\text { H/WF }\end{array}$} \\
\hline & $\begin{array}{l}\text { 岳父 } \\
\text { WF }\end{array}$ & & $\begin{array}{l}\text { Тесть } \\
\text { WF }\end{array}$ & \\
\hline \multirow[t]{2}{*}{2} & $\begin{array}{l}\text { 婆婆 } \\
\mathrm{HM}\end{array}$ & \multirow{2}{*}{$\begin{array}{l}\text { Қайын апа } \\
\text { H/WM }\end{array}$} & $\begin{array}{l}\text { Свекровь } \\
\text { НМ }\end{array}$ & \multirow{2}{*}{$\begin{array}{l}\text { Mother-in-law } \\
\text { H/WM }\end{array}$} \\
\hline & $\begin{array}{l}\text { 岳母 } \\
\text { WM }\end{array}$ & & $\begin{array}{l}\text { Теща } \\
\text { WM }\end{array}$ & \\
\hline \multirow{6}{*}{3} & $\begin{array}{l}\text { 大伯子 } \\
\mathrm{HBe}\end{array}$ & $\begin{array}{l}\text { Қайын аға } \\
\text { НВе }\end{array}$ & Деверь & \multirow{6}{*}{$\begin{array}{l}\text { Brother-in-law } \\
(\mathrm{H} / \mathrm{WB}) /(\mathrm{SH})\end{array}$} \\
\hline & $\begin{array}{l}\text { 小叔子 } \\
\text { HBy }\end{array}$ & $\begin{array}{l}\text { Қайын іні } \\
\text { НВу }\end{array}$ & HB & \\
\hline & $\begin{array}{l}\text { 内兄 } \\
\text { WBe }\end{array}$ & $\begin{array}{l}\text { Қайын аға } \\
\text { WBe }\end{array}$ & \multirow{2}{*}{$\begin{array}{l}\text { Шурин } \\
\text { WB }\end{array}$} & \\
\hline & $\begin{array}{l}\text { 内弟 } \\
\text { WBy }\end{array}$ & $\begin{array}{l}\text { Қайын іні } \\
\text { WBy }\end{array}$ & & \\
\hline & $\begin{array}{l}\text { 姐夫 } \\
\mathrm{SeH}\end{array}$ & $\begin{array}{l}\text { Жезде } \\
\mathrm{SeH}\end{array}$ & \multirow{2}{*}{$\begin{array}{l}\text { Зять } \\
\text { S/DH }\end{array}$} & \\
\hline & $\begin{array}{l}\text { 妹夫 } \\
\text { SyH }\end{array}$ & $\begin{array}{l}\text { Күйеу бала } \\
\text { SуH }\end{array}$ & & \\
\hline \multirow{6}{*}{4} & $\begin{array}{l}\text { 大姑子 } \\
\mathrm{HSe}\end{array}$ & $\begin{array}{l}\text { Қайын апа } \\
\text { HSe }\end{array}$ & \multirow{2}{*}{$\begin{array}{l}\text { Золовка } \\
\text { HS }\end{array}$} & \multirow{6}{*}{$\begin{array}{l}\text { Sister-in-law } \\
(\mathrm{H} / \mathrm{WS}) /(\mathrm{BW})\end{array}$} \\
\hline & $\begin{array}{l}\text { 小姑子 } \\
\text { HSy }\end{array}$ & $\begin{array}{l}\text { Қайын сіңлі } \\
\text { HSy }\end{array}$ & & \\
\hline & $\begin{array}{l}\text { 大姨子 } \\
\text { WSy }\end{array}$ & $\begin{array}{l}\text { Қайын апа } \\
\text { WSy }\end{array}$ & \multirow{2}{*}{$\begin{array}{l}\text { Свояченица } \\
\text { WS }\end{array}$} & \\
\hline & $\begin{array}{l}\text { 小姨子 } \\
\text { WSe }\end{array}$ & $\begin{array}{l}\text { Қайын сіңлі } \\
\text { WSe }\end{array}$ & & \\
\hline & $\begin{array}{l}\text { 嫂子 } \\
\text { BeW }\end{array}$ & $\begin{array}{l}\text { Жеңге } \\
\text { BeW }\end{array}$ & \multirow{2}{*}{$\begin{array}{l}\text { Невестка } \\
\mathrm{B} / \mathrm{SW}\end{array}$} & \\
\hline & $\begin{array}{l}\text { 弟媳妇 } \\
\text { ByW }\end{array}$ & $\begin{array}{l}\text { Келін } \\
\text { ВуW }\end{array}$ & & \\
\hline 5 & $\begin{array}{l}\text { 女媳 } \\
\text { DH }\end{array}$ & Күйеу бала & $\begin{array}{l}\text { Зять } \\
\text { S/DH }\end{array}$ & Son-in-law \\
\hline 6 & $\begin{array}{l}\text { 儿媳妇 } \\
\text { SW }\end{array}$ & Келін & $\begin{array}{l}\text { Невестка } \\
\mathrm{B} / \mathrm{SW}\end{array}$ & Daughter-in-law \\
\hline
\end{tabular}

We can notice from the chart that Chinese and Kazakh languages are more similar than Russian and English languages. If we fully study the words in groups 1 and 2, they mean male and female gender of the supreme generation. Here we can see acompletecorrespondence of Kazakh and English as well as Chinese and Russian languages. That is in Chinese and Russian languages they pay attention not only to the gender of the supreme generation in marital relations but also to whether daughter or son continues it.

In Kazakh and English languages, they divide the supreme generation only by gender. Groups 3 and 4 show gender of marital relations of the middle generation. In this group, none of the languages corresponds fully. In Chinese language kinship terminology depends not only on gender but, also on whether it is of husband or wife's side, as well as the age difference. Thus, each kinship terminology has its own nomination. As for the Kazakh language, there are respective nominations depending on gender and age difference as in Chinese language. 
However, there is a common “Қайын”for both husband's and wife's relatives. On the contrary, in Russian they specify whether kinship belongs to husband or wife but age difference is not important. English language is the simplest among these ones, only gender is important, age and affiliation is insignificant, so they use common terminology for all. The words in groups 5 and 6 show gender of the lowest generation of marital relations.

Let us compare kinship terminology of indirect blood relations derived from kinship of the second degree in Chinese language with the same in Kazakh, Russian and English languages. Look at Chart 6:

Chart 6

Indirect Blood kinship Group

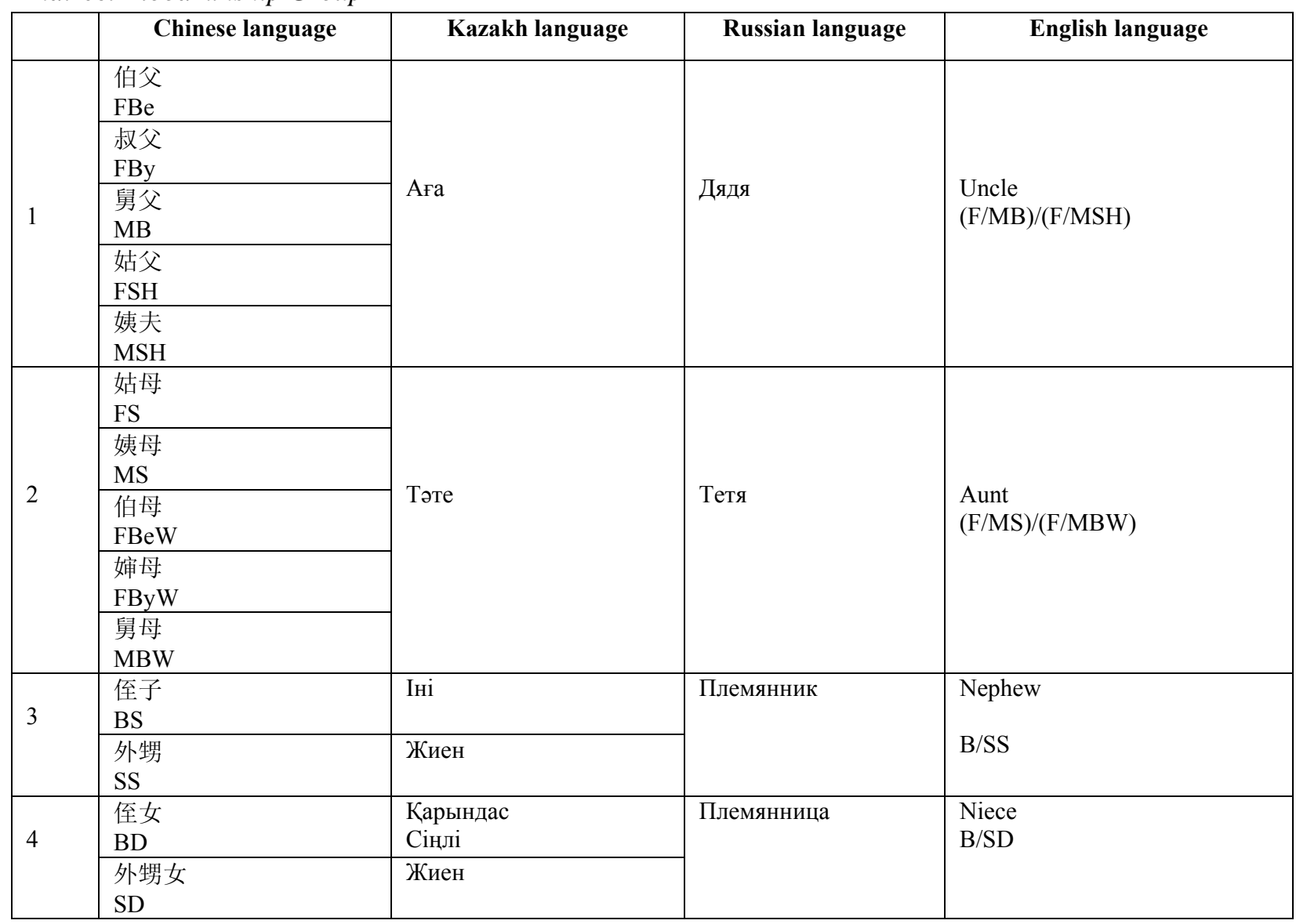

Indirect blood kinship groups in English and Russian have no differences. Kazakh language is slightly different from them. As for Chinese language, it is totally different. Groups 1 and 2 show male and female kinship terminology of the supreme indirect generation. In this group Kazakh, Russian and English languages are very similar to each other. Kinship terminology depends only on gender. That is "Аға" in Kazakh corresponds to “Дядя" in Russian and"Uncle"in English. It is a common nomination for all men of the supreme generation; also, it is not important whether he is from father or mother's side. In this case, Chinese language is different. Each kinship nomination depends on gender, age as well as whether they are from father or mother's side. Groups 3 and 4 show male and female kinship nominations of the next indirect generation. Also in this group, Russian and English languages have no difference. Only gender matters. In Kazakh language, if the next 
indirect generation derives from elder or younger brother the generation is distinguished by gender. For example, "Iні” ("Younger brother"), "Қарындас" ("Younger sister"). If indirect generation derives from daughter that is from elder and younger sister it is called "Жиен” "no matter the gender. In Chinese language, all these nominations have their own terminology.

Chart 7 gives us the comparison of kinship terminology of the third degree:

\section{Chart 7}

Kinship Terminology of the Third Degree

\begin{tabular}{|c|c|c|c|}
\hline Chinese language & Kazakh language & Russian language & English language \\
\hline $\begin{array}{l}\text { 堂兄 } \\
\text { FBSe }\end{array}$ & Аға & \multirow[t]{4}{*}{ Двоюродный брат } & \multirow{8}{*}{$\begin{array}{l}\text { Cousin } \\
\text { F/MB/SS/D }\end{array}$} \\
\hline $\begin{array}{l}\text { 堂弟 } \\
\text { FBSy }\end{array}$ & Іні & & \\
\hline $\begin{array}{l}\text { 表哥 } \\
(\mathrm{FS}) /(\mathrm{MB} / \mathrm{S}) \mathrm{Se}\end{array}$ & Аға & & \\
\hline $\begin{array}{l}\text { 表弟 } \\
(\mathrm{FS}) /(\mathrm{MB} / \mathrm{S}) \mathrm{Sy}\end{array}$ & Іні & & \\
\hline $\begin{array}{l}\text { 堂姐 } \\
\text { FBDe } \\
\end{array}$ & Әпке & \multirow[t]{4}{*}{ Двоюродная сестра } & \\
\hline $\begin{array}{l}\text { 堂妹 } \\
\text { FBDy }\end{array}$ & $\begin{array}{l}\text { Қарындас } \\
\text { Сіңлі }\end{array}$ & & \\
\hline $\begin{array}{l}\text { 表姐 } \\
(\mathrm{FS}) /(\mathrm{MB} / \mathrm{S}) \mathrm{De}\end{array}$ & Әпке & & \\
\hline $\begin{array}{l}\text { 表妹 } \\
(\mathrm{FS}) /(\mathrm{MB} / \mathrm{S}) \mathrm{Dy}\end{array}$ & $\begin{array}{l}\text { Қарындас } \\
\text { Сіңлі }\end{array}$ & & \\
\hline
\end{tabular}

We can notice from Chart 7 that the four languages do not correspond at all to each other. Chinese language is the most complicated and it considers kinship nominations systematically. That is, kinship terminology identifies degree, age and affiliation. In Kazakh language as it is mentioned above, they distinguish age and gender and Russian language distinguishes only gender. English language is the simplest one among these languages because it does not characterize anything and is limited by "Cousin".

Summarizing comparison given above we can conclude that Chinese, Kazakh, Russian and English languages have similarities as well as many differences. Main differences are:

1. Chinese kinship terminology is divided in several stages depending on gender. That is, kinship terminology of the first degree consists of one stage, kinship terminology of the second degree consists of two stages and kinship terminology of the third degree consists of three stages. The semantic analysis of the 58 Chinese words given above proves it.

2. The modern Chinese language distinguishes kinship terminology of one generation by age difference. The 28 words given above prove it. Although these features are not available in Russian or English, we cannot exclude that they exist in Kazakh.

\section{Conclusion}

Chinese language subdivides kinship terminology into degrees and stages and composes a kinship terminology system. This system is considered to be the most complicated among the world's kinship terminologies. Concluding, if we compare kinship terminology of the first level in Chinese with the same in the 
other languages there is no significant difference. The main peculiarities can be noticed in kinship terminology of the second and mostly the third level. Thus, we have convinced that kinship terminology in Chinese pays attention to age difference, generation's gender as well as mostly whether kinship is related to husband or wife's party.The main reason of it takes its roots from the ancient Chinese emperor society. In order to save the rank of the Emperor and his vassals in the society the kinship system was strictly controlled during the epochs of Tsin and Khan. As a result, this system is still actual in the modern Chinese language.

\section{References}

Диуанова Р. К. (2010). Қазақ тіліндегі туыстық атаулардың мағыналық құрылымы мен лексикографиялану ерекшеліктері.// А.Байтұрсынұлы атындағы Тіл Білімі Институты. Алматы,.

Жолдасбек Л.О. (1998). Қазақ сөйленістеріндегі туыстық атаулар. // А.Байтұрсынұлы атындағы Тіл Білімі Институты. -Алматы.

王力, 王学元. (1988). 《汉语称谓词典》. 辽宁大学出版社.

胡士云. (2007). 《汉语亲属称谓研究》。商务印书馆.

贾彦德. (1994). 现代汉语常用亲属词的语义特点。世界汉语教学，第1期(总第27期)。

陈月明. (1990). 现代汉语亲属称谓系统以及文化印记. 《汉语学习》, 第5期, pp. 57-60.

《现代汉语词典》.(2012.) 商务印书馆. 